\title{
ANALISIS DAMPAK PERUBAHAN IKLIM TERHADAP TINGKAT KESEJAHTERAAN NELAYAN DI DESA SUNGAI KAKAP KABUPATEN KUBU RAYA
}

\author{
Tezario Chandra Putra Parura ${ }^{1}$, Kartini $^{2}$, Erni Yuniarti ${ }^{1}$ \\ ${ }^{1}$ Program Studi Teknik Lingkungan, Fakultas Teknik, Universitas Tanjungpura, Pontianak \\ ${ }^{2}$ Program Studi Teknik Sipil, Fakultas Teknik, Universitas Tanjungpura, Pontianak \\ Email: ryoku_teza@yahoo.com
}

\begin{abstract}
ABSTRAK
Pemanasan global berdampak pada perubahan iklim dan berimplikasi terhadap sektor kelautan. Dampak yang paling nyata adalah berubahnya pola presipitasi serta arah dan kecepatan angin sehingga berdampak pula terhadap hasil tangkapan nelayan. Penelitian ini bertujuan untuk: (1) menganalisis dampak yang ditimbulkan akibat perubahan iklim terhadap sektor perikanan di Desa Sungai Kakap; (2) mengestimasi besarnya tingkat kesejahteraan nelayan di Desa Sungai Kakap sebagai akibat terjadinya perubahan iklim; (3) menganalisis strategi adaptasi yang dilakukan oleh nelayan di Desa Sungai Kakap dalam menghadapi perubahan iklim. Metoda yang digunakan dalam penelitian ini adalah membandingkan tren hasil tangkapan nelayan dengan kondisi iklim yang terjadi. Untuk mengestimasi besarnya tingkat kesejahteraan nelayan dhitung menggunakan Nilai Tukar Nelayan, sementara analisis adaptasi nelayan menggunakan metode analisis deskriptif. Hasil penelitian menunjukkan bahwa faktor yang memiliki dampak paling besar terhadap turunnya hasil tangkapan nelayan adalah curah hujan, karena lingkup penelitian ini dibatasi pada daerah pesisir sehingga arah dan kecepatan angin serta tinggi gelombang tidak memberi dampak terhadap nelayan dalam melaut. Curah hujan yang tinggi berdampak terhadap salinitas air laut sehingga menyebabkan turunnya hasil tangkapan nelayan. Curah hujan rata-rata dalam kurun waktu 2008-2012 di Sungai Kakap adalah 2.662,4 mm dengan penurunan hasil tangkapan dari tahun 2009-2012 sebesar 3.316,7 ton. Nilai Tukar Nelayan (NTN) di Desa Sungai Kakap Tahun 2012 sebesar 0,84 yang mengindikasikan keluarga nelayan di Desa Sungai Kakap mempunyai daya beli yang rendah dalam memenuhi kebutuhan keluarganya dan mengalami defisit anggaran rumah tangga. Pola adaptasi yang dilakukan nelayan dalam menghadapi perubahan iklim tersebut adalah dengan menerapkan pola pemasukan ganda, yaitu dengan mencari tambahan pemasukan melalui usaha non perikanan.
\end{abstract}

Kata Kunci: perubahan iklim, nelayan, kesejahteraan

\begin{abstract}
Global warming impacts on the climate change and it has implication for the marine sector. The most tangible impact are shown on the changing patterns of precipitation, wind speed and direction that impacted on the production of fishermen. The aims of the research are: (1) to analyze the impact of the climate change on the fisheries sector in Sungai Kakap village; (2) to estimate the magnitude of welfare of fishermen in Sungai Kakap village as a result of the climate change; (3) to analyze adaptation strategies which undertaken by the fishermen in Sungai Kakap village towards the climate change. The method used in this research are to compare the trend of fishermen productions by ckimatic condition that happened. To estimate the magnitude of the welfare of fishermen, the writer used Fishermen Exchange Value (NTN). Meanwhile, analyzing of adaptation strategies using methods of descriptive analysis. Results of research shown that the greatest impaact factor towards om the smaller cathes is in the rain falling precipitation, since the scope of this research is limited to the coastal areas, it towards that the wind direction and speed also wave height doesn't give any effect to fishermen. High precipitaion caused the salinity of sea water results decreasing of fishermen production. The average precipitation in the period 2008-2012 in Sungai Kakap is 2.662,4 mm with decreasing of fishermen production in the period 2009-2012 ammounted to 3.316,7 tons. Fishermen Exchange Value (NTN) is 0,84 which indicates that fishermen families have low purchasing in fulfilling their needs also budget deficit. Adaptation strategy for climate change is to apply double incomes through non fishing effort.
\end{abstract}

Keywords: climate change, fishermen, prosperity 


\section{Pendahuluan}

Pemanasan global merupakan suatu proses peningkatan temperatur bumi. Salah satu efek dari pemanasan global yaitu berubahnya iklim di berbagai belahan dunia. Perubahan iklim berdampak pada berbagai sektor dan sangat kompleks karena mencakup berbagai aspek kehidupan manusia. Di sektor kelautan perubahan iklim mengakibatkan kenaikan suhu permukaan air laut; peningkatan frekuensi dan intensitas cuaca ekstrim; perubahan pola curah hujan dan limpasan air tawar yang dipicu oleh fenomena El-Nino dan La-Nina; perubahan pola sirkulasi laut dan kenaikan muka air laut.

Kecamatan Sungai Kakap terbagai atas beberapa gugus pulau. Beberapa pulau berbatasan langsung dengan Laut Natuna. Kondisi alam demikian telah menjadikan Wilayah Kecamatan Kakap bagian pesisir seperti seperti Tanjung Saleh, Jeruju Besar, Sungai Itik, dan Sungai Kupah (Tanjung Intan) memiliki potensi perikanan. Muara Sungai Kakap (Tanjung Saleh) dan sekitarnya adalah tempat favorit bagi para nelayan untuk menangkap ikan. Namun Kecamatan Sungai Kakap sebagai salah satu kawasan penting dalam pemanfaatan potensi perikanan di Kota Pontianak turut merasakan dampak perubahan iklim yang terjadi. Cuaca yang tidak menentu (hujan dan angin kencang) membuat para nelayan kesulitan untuk pergi melaut. Pada keadaan normal, angin akan bertiup dari Timur Laut sampai Barat dengan kecepatan 2-12 knot, sedangkan bila iklim sedang tidak bersahabat angin bertiup hingga kecepatan 35 knot sehingga nelayan tidak berani melaut.

Melihat kondisi tersebut maka perlu dilakukan penelitian untuk menganalisis dampak perubahan iklim terhadap tingkat kesejahteraan nelayan di Desa Sungai Kakap. Analisis dilakukan mulai dari mengumpulkan data iklim, observasi terhadap responden, hingga menarik kesimpulan.

\section{Metode Penelitian}

\section{Dampak Perubahan Iklim Terhadap Sektor Perikanan di Desa Sungai Kakap}

Data mengenai jumlah tangkapan berguna untuk melihat tren yang terjadi, apakah mengalami peningkatan atau penurunan. Selanjutnya data tersebut akan disajikan dalam bentuk grafik. Hal ini bertujuan untuk mempermudah analisis. Setelah data tersebut terkumpul, dibuat hipotesis mengenai ada tidaknya perubahan dalam tren produksi perikanan. Kemudian hasilnya dibandingkan dengan data kondisi cuaca yang terjadi pada saat itu. Pada akhirnya terlihat bahwa perubahan iklim akan menyebabkan perubahan hasil tangkapan nelayan.

Menurut Harto (2000), untuk mendukung hasil analisa diperlukan nilai korelasi antara data kondisi cuaca dengan hasil tangkapan dengan menggunakan rumus:

$\mathrm{K}=\frac{n \cdot\left(\sum X Y\right)-\left(\sum X\right)\left(\sum Y\right)}{\left[n\left(\sum Y^{2}\right)-\left(\sum Y\right)^{2}\right]^{0.5}\left[n\left(\sum X^{2}\right)-\left(\sum X\right)^{2}\right]^{0.5}}$

Keterangan:

$\mathrm{K}=$ koefisien korelasi

$\mathrm{X}=$ curah hujan

$\mathrm{Y}=$ hasil tangkapan nelayan

$\mathrm{n}=$ jumlah data

\section{Estimasi Tingkat Kesejahteraan Nelayan di Desa Sungai Kakap Berdasarkan Nilai Tukar Nelayan}

Analisis kesejahteraan dalam penelitian ini menggunakan Nilai Tukar nelayan (NTN). Menurut Ustriyana (2005), konsep NTN merupakan indikator untuk mengukur tingkat kesejahteraan masyarakat nelayan secara relatif. NTN juga digunakan untuk mengukur kemampuan keluarga nelayan untuk memenuhi kebutuhan subsistensinya. NTN diperoleh dari perbandingan antara penerimaan rumah tangga nelayan dengan pengeluaran rumah tangga nelayan dalam 1 tahun. NTN dapat bernilai lebih rendah, sama, atau lebih tinggi dari satu. NTN lebih rendah dari satu artinya keluarga nelayan mempunyai daya beli yang rendah dalam memenuhi kebutuhan hidupnya dan berpotensi mengalami defisit anggaran rumah tangga. NTN yang berada di sekitar angka satu artinya 
keluarga nelayan hanya dapat memenuhi kebutuhan subsistennya saja. Jika NTN lebih tinggi dari satu artinya keluarga nelayan selain dapat memenuhi kebutuhan subsistennya juga dapat memenuhi kebutuhan sekunder atau tersiernya, atau menabung dalam bentuk investasi barang.

\section{Strategi Adaptasi Nelayan di Desa Sungai Kakap dalam Menghadapi Perubahan Iklim}

Strategi adaptasi nelayan di Desa Sungai Kakap akan dianalisis menggunakan analisis deskriptif. Analisis deskriptif yang dilakukan adalah dengan melihat bagaimana cara nelayan dalam beradaptasi akibat terjadinya perubahan iklim, baik secara ekonomi maupun teknologi. Secara ekonomi, nelayan akan mencari sumber pendapatan lainnya apabila dia tidak melaut pada saat cuaca buruk. Secara teknologi, nelayan akan mencari teknologi yang lebih canggih untuk digunakan pada saat melaut. Selanjutnya, rekomendasi kebijakan di bidang kemanusiaan, ekosistem, dan pemerintahan menjadi solusi untuk mengurangi dampak perubahan iklim dan meningkatkan kesejahteraan nelayan.

\section{Hasil dan Pembahasan}

A. Dampak Perubahan Iklim Terhadap Sektor Perikanan di Sungai Kakap Jumlah curah hujan di Sungai Kakap cenderung mengalami peningkatan dari tahun 2008 hingga 2010. Pada tahun 2008, jumlah curah hujan yang tercatat di Pos Hujan Sungai Kakap adalah 2471 mm. Jumlah tersebut terus meningkat hingga tahun 2010 curah hujan yang tercatat adalah $3133 \mathrm{~mm}$. Kemudian mengalami penurunan hingga tahun 2012 curah hujan yang tercatat di Pos Hujan Sungai Kakap adalah 2405 mm. Perkembangan curah hujan di Sungai Kakap dapat dilihat pada Tabel 1.

Tabel 1. Perkembangan Curah Hujan di Sungai Kakap

\begin{tabular}{lccccc}
\hline \multirow{1}{*}{ Bulan } & \multicolumn{5}{c}{ Curah Hujan $\mathbf{( m m )}$} \\
\cline { 2 - 6 } & $\mathbf{2 0 0 8}$ & $\mathbf{2 0 0 9}$ & $\mathbf{2 0 1 0}$ & $\mathbf{2 0 1 1}$ & $\mathbf{2 0 1 2}$ \\
\hline Januari & 62 & 198 & 251 & 200 & 148 \\
Februari & 149 & 16 & 274 & 60 & 109 \\
Maret & 148 & 197 & 446 & 55 & 90 \\
April & 137 & 458 & 66 & 178 & 232 \\
Mei & 117 & 51 & 136 & 181 & 249 \\
Juni & 116 & 73 & 226 & 106 & 118 \\
Juli & 269 & 114 & 365 & 227 & 251 \\
Agustus & 219 & 238 & 204 & 272 & 70 \\
September & 201 & 155 & 322 & 147 & 67 \\
Oktober & 355 & 310 & 259 & 396 & 301 \\
November & 229 & 525 & 266 & 327 & 295 \\
Desember & 475 & 447 & 318 & 366 & 475 \\
\hline Jumlah & $\mathbf{2 4 7 7}$ & $\mathbf{2 7 8 2}$ & $\mathbf{3 1 3 3}$ & $\mathbf{2 5 1 5}$ & $\mathbf{2 4 0 5}$ \\
\hline
\end{tabular}

Sumber: Badan Meteorologi, Klimatologi, dan Geoofisika Stasiun Klimatologi Siantan, 2013

Data angin diperlukan untuk peramalan tinggi dan periode gelombang. Mengingat data angin di lokasi penelitian tidak tersedia, maka digunakan data angin dari Stasiun Meteorologi Maritim Pontianak, yang kemudian diinterpolasi dengan koordinat lokasi penelitian sehingga hasilnya representatif. Kecepatan angin diukur dengan anemometer, dan dinyatakan dalam satuan knot. Jumlah data angin yang ditampilkan setiap jam selama beberapa tahun pengamatan adalah sangat besar. Untuk itu data tersebut harus diolah dan disajikan dalam bentuk ringkasan atau diagram yang disebut dengan mawar angin (windrose). Dengan diagram mawar angin tersebut maka karakteristik angin dapat dibaca dengan cepat. Diagram windrose Sungai Kakap Tahun 2008-2012 ditampilkan pada Gambar 1. 


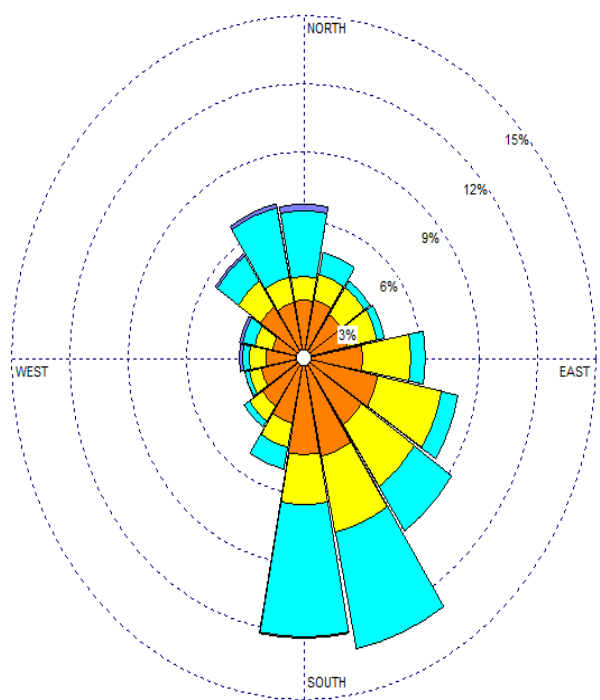

(a) Tahun 2008

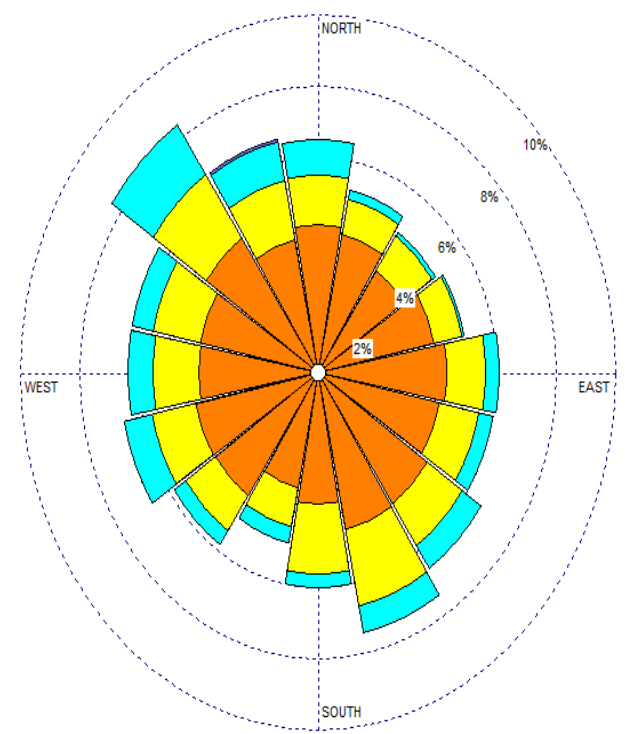

(c) Tahun 2010

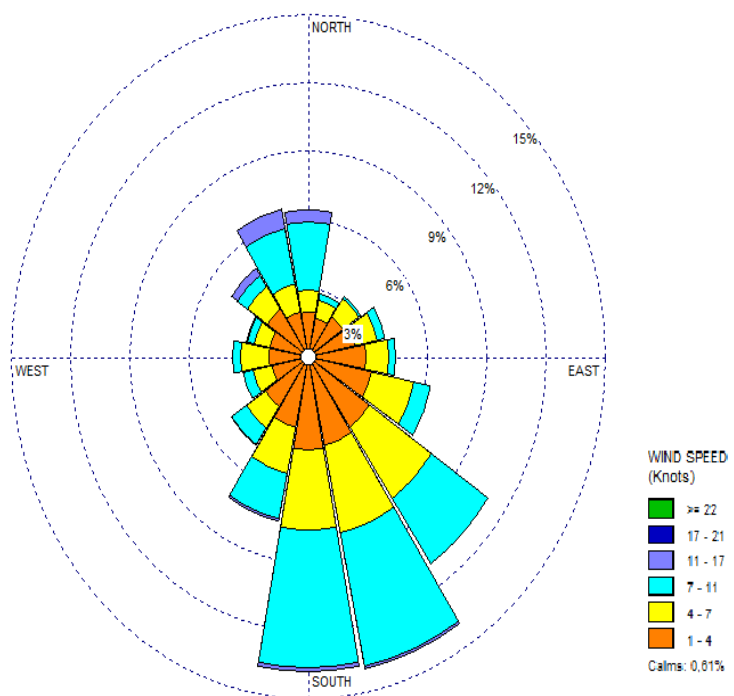

(b) Tahun 2009

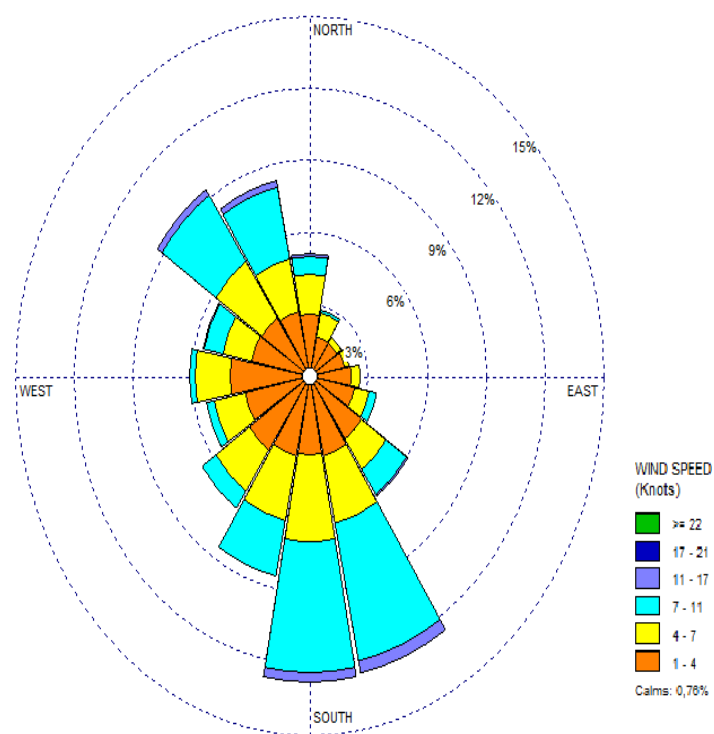

(d) Tahun 2011

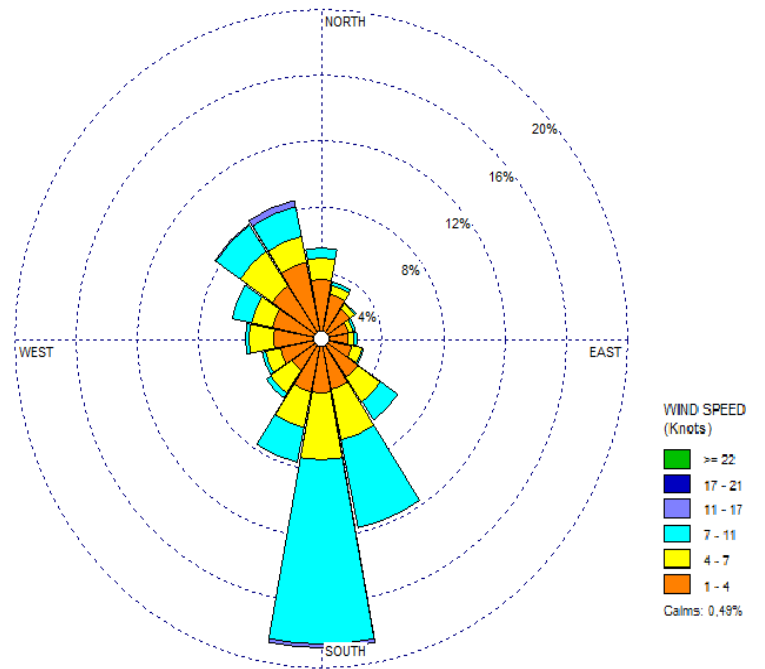

(e) Tahun 2012

Gambar 1. Diagram windrose Sungai Kakap Tahn 2008-2012 
Dari Gambar 1 dapat diketahui bahwa pada Tahun 2008 distribusi angin dominan berhembus dari arah Selatan Tenggara dengan rentang kecepatan maksimal 7-11 knot; pada Tahun 2009 distribusi angin dominan berhembus dari arah Selatan Tenggara dan Selatan dengan rentang kecepatan maksimal 7-11 knot; pada Tahun 2010 distribusi angin datang dari segala arah 16 mata angin dengan intensitas yang hampir sama dan yang dominan berhembus dari arah Barat Laut dengan rentang kecepatan maksimal 7-11 knot disebabkan oleh fenomena El-Nino yang terjadi di Indonesia pada tahun 2010 silam; pada Tahun 2011 distribusi angin dominan berhembus dari arah Selatan Tenggara dan Selatan dengan rentang kecepatan maksimal 7-11 knot; dan pada Tahun 2012 distribusi angin dominan berhembus dari arah Selatan dengan rentang kecepatan maksimal 7-11 knot.

Dalam penelitian ini tidak dilakukan pengukuran gelombang, mengingat kesulitan dan biaya yang sangat besar. Selain itu pengukuran yang dilakukan dalam waktu pendek kurang dapat mewakili tinggi gelombang sesungguhnya di lapangan. Oleh karena itu digunakan data sekunder yaitu data gelombang yang diramalkan dari data angin. Tinggi gelombang rata-rata di perairan Sungai Kakap adalah 0,58 meter pada tahun 2008, 0,57 meter pada tahun 2009, 0,38 meter pada tahun 2010, 0,59 meter pada tahun 2011, dan 0,54 meter pada tahun 2012. Data tinggi gelombang dapat dilihat pada Tabel 2.

Tabel 2. Data tinggi gelombang di perairan Sungai Kakap tahun 2008-2012

\begin{tabular}{lccccc}
\hline \multirow{1}{*}{ Bulan } & \multicolumn{5}{c}{ Tinggi Gelombang (m) } \\
\cline { 2 - 6 } & $\mathbf{2 0 0 8}$ & $\mathbf{2 0 0 9}$ & $\mathbf{2 0 1 0}$ & $\mathbf{2 0 1 1}$ & $\mathbf{2 0 1 2}$ \\
\hline Januari & 0,78 & 1,22 & 0,66 & 0,88 & 0,87 \\
Februari & 0,94 & 0,60 & 0,32 & 0,65 & 0,40 \\
Maret & 0,42 & 0,26 & 0,29 & 0,49 & 0,42 \\
April & 0,22 & 0,31 & 0,20 & 0,32 & 0,22 \\
Mei & 0,53 & 0,27 & 0,22 & 0,25 & 0,32 \\
Juni & 0,49 & 0,48 & 0,26 & 0,55 & 0,63 \\
Juli & 0,65 & 0,66 & 0,28 & 0,67 & 0,75 \\
Agustus & 0,58 & 0,73 & 0,35 & 0,71 & 0,92 \\
September & 0,60 & 0,75 & 0,26 & 0,75 & 0,79 \\
Oktober & 0,36 & 0,42 & 0,46 & 0,41 & 0,40 \\
November & 0,43 & 0,66 & 0,48 & 0,50 & 0,32 \\
Desember & 1,00 & 0,52 & 0,83 & 0,93 & 0,47 \\
\hline Rata-rata & $\mathbf{0 , 5 8}$ & $\mathbf{0 , 5 7}$ & $\mathbf{0 , 3 8}$ & $\mathbf{0 , 5 9}$ & $\mathbf{0 , 5 4}$ \\
\hline
\end{tabular}

Sumber: Badan Meteorologi, Klimatologi, dan Geofisika Stasiun Maritim Pontianak, 2013

Tabel 2 menunjukkan bahwa fluktuasi tinggi gelombang di perairan Sungai Kakap dalam rentang waktu lima tahun cenderung stabil. Hanya pada tahun 2010 tinggi gelombang mengalamani penurunan namun tidak signifikan.

Menurut data yang diperoleh dari Dinas Kelautan dan Perikanan Kabupaten Kubu Raya, dalam kurun waktu empat tahun (2009-2012) volume produksi nelayan di Sungai Kakap cenderung mengalami penurunan. Penurunan yang drastis terjadi pada tahun 2012 yaitu mengalami penurunan volume produksi sebesar 1907,2 ton dibandingkan pada tahun 2011. Perkembangan volume produksi nelayan di Desa Sungai Kakap dapat dilihat pada Gambar 2. 


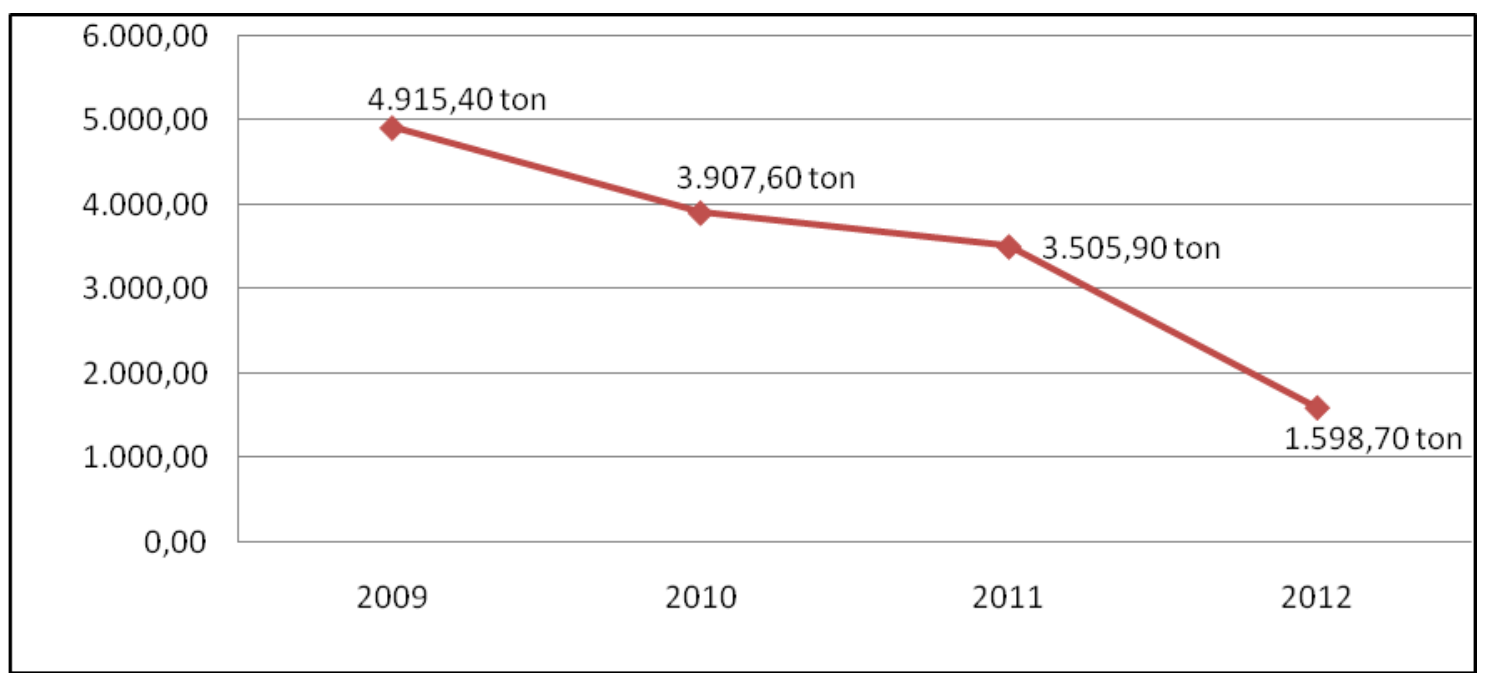

Gambar 2. Grafik perkembangan volume produksi nelayan di Desa Sungai Kakap tahun 2009-2012 Sumber: Dinas Kelautan dan Perikanan Kabupaten Kubu Raya, 2013

Secara umum, volume produksi tangkapan nelayan di Sungai Kakap mengalami tren penurunan dalam kurun waktu empat tahun terakhir. Pada tahun 2009 hasil tangkapan nelayan mencapai 4.915,40 ton, namun pada tahun 2010 mengalami penurunan sebesar 20\% menjadi 3.907,6 ton. Volume produksi nelayan terus mengalami penurunan, di tahun 2011 turun sebanyak 10,3\% menjadi $3.505,9$ ton, dan di tahun 2012 volume produksi nelayan turun drastis sebanyak 54,4\% menjadi $1.598,7$ ton. Secara khusus, dampak dari perubahan iklim dapat dilihat dari penurunan volume produksi ikan oleh nelayan di Sungai Kakap tahun 2009-2012. Hal tersebut dapat dibuktikan oleh data yang dimiliki oleh Dinas Perikanan dan Kelautan Kabupaten Kubu Raya. Bukti lainnya yaitu data iklim yang dimiliki oleh BMKG dari tahun 2008-2012. Data tersebut membuktikan bahwa telah terjadi tren peningkatan curah hujan di Sungai Kakap selama kurun waktu lima tahun, meskipun data tinggi gelombang perairan di Sungai Kakap menunjukkan bahwa dalam kurun waktu lima tahun tidak pernah terjadi gelombang tinggi hingga mencapai dua meter. Gelombang tertinggi dalam kurun lima tahun terjadi pada bulan Januari tahun 2009 yaitu setinggi lebih dari satu meter. Selanjutnya data iklim dan data volume produksi nelayan tersebut akan digabungkan sehingga dapat diamati bagaimana dampak perubahan iklim terhadap produksi nelayan di Sungai Kakap.

Tabel 3. Perbandingan kondisi iklim dengan hasil produksi nelayan di Sungai Kakap Tahun 2009-2012

\begin{tabular}{ccccc}
\hline \multirow{2}{*}{ Tahun } & \multicolumn{3}{c}{ Kondisi Iklim } & \\
\cline { 2 - 4 } & $\begin{array}{c}\text { Curah Hujan } \\
(\mathbf{m m})\end{array}$ & $\begin{array}{c}\text { Kecepatan Angin } \\
\text { (knots) }\end{array}$ & $\begin{array}{c}\text { Tinggi Gelombang } \\
(\mathbf{m})\end{array}$ & $\begin{array}{c}\text { Produksi } \\
\text { Ikan (ton) }\end{array}$ \\
\hline 2009 & 2782 & 5,30 & 0,57 & $4.915,40$ \\
2010 & 3133 & 3,83 & 0,38 & $3.907,60$ \\
2011 & 2515 & 5,06 & 0,59 & $3.505,90$ \\
2012 & 2405 & 5,03 & 0,54 & $1.598,70$ \\
\hline
\end{tabular}

Dari tabel 5.4 dapat dilihat bahwa intensitas curah hujan di Sungai Kakap tergolong tinggi, bahkan di tahun 2010 terjadi peningkatan intensitas curah hujan yang cukup signifikan yang disebabkan fenomena El-Nino yang terjadi di Indonesia pada tahun 2010. Tinggi gelombang rata-rata di perairan Sungai Kakap dari tahun 2009 hingga 2012 masih dalam kategori normal yaitu kisaran 0,5 meter dan 
tidak menjadi faktor penghalang bagi nelayan dalam mencari ikan. Namun hasil produksi nelayan dari tahun 2009 hingga 2012 terus mengalami penurunan, hingga pada tahun 2012 mengalami penurunan yang cukup drastis hingga mencapai 54\%. Nilai koefisien korelasi antara curah hujan dengan hasil tangkapan nelayan adalah 0,632, artinya tingkat curah hujan dengan hasil tangkapan nelayan di Sungai Kakap memiliki korelasi / hubungan ketergantungan satu dengan yang lain sebesar $63 \%$. Oleh karena itu tren penurunan hasil tangkapan nelayan merupakan dampak dari curah hujan yang tinggi pada kawasan perairan Sungai Kakap yang menyebabkan terganggunya salinitas (kadar garam) pada kawasan perairan tersebut. Perubahan salinitas di daerah pesisir relatif besar dibandingkan dengan perubahan salinitas di laut terbuka, karena memiliki masukan air tawar baik secara langsung dari hujan maupun dari sungai terutama saat musim hujan. Menurut Hayes dan Laevastu (1982) faktor - faktor yang mempengaruhi salinitas antara lain:

1. Penguapan (Evaporasi). Makin besar tingkat penguapan air laut di suatu wilayah, maka salinitasnya tinggi dan sebaliknya pada daerah yang rendah tingkat penguapan air lautnya, maka daerah itu rendah kadar garamnya.

2. Curah hujan (Presipitasi). Makin besar/banyak curah hujan di suatu wilayah laut maka salinitas air laut itu akan rendah dan sebaliknya makin sedikit/kecil curah hujan yang turun salinitas akan tinggi.

3. Banyak sedikitnya sungai yang bermuara di laut tersebut, makin banyak sungai yang bermuara ke laut tersebut maka salinitas laut tersebut akan rendah, dan sebaliknya makin sedikit sungai yang bermuara ke laut tersebut maka salinitasnya akan tinggi.

Curah hujan (presipitasi) yang tinggi di perairan Kakap mengakibatkan menurunnya kadar salinitas air di kawasan pesisir Kakap. Selain itu, sungai Kakap yang bermuara di kawasan pesisir Kakap juga memberi dampak terhadap tingkat salinitas air akibat limpasan air tawar yang tinggi dari sungai ketika terjadi hujan, hal tersebut berdampak kepada orientasi migrasi dan distribusi ikan di kawasan perairan tersebut, sehingga hasil tangkapan nelayan pun ikut berkurang. Secara tidak langsung, perubahan iklim yang ditandai dengan curah hujan ekstrim memberi dampak kepada nelayan Sungai Kakap yaitu berkurangnya hasil tangkapan dalam kurun waktu 2009-2012.

\section{B. Estimasi Tingkat Kesejahteraan Nelayan di Desa Sungai Kakap}

Data pendapatan nelayan pada tahun 2012 merupakan data sekunder yang didapat dari catatan pembukuan oleh Ketua KUB (Kelompok Usaha Bersama) yang menaungi para nelayan di Desa Sungai Kakap yang menjadi responden pada penelitian ini. Sedangkan data pengeluaran nelayan merupakan data primer yang didapat dari hasil pengisian kuesioner, mencakup pengeluaran untuk biaya kebutuhan rumah tangga, biaya pendidikan, biaya listrik, biaya transportasi, dan biaya lain-lain.

Dari hasil analisis data pendapatan nelayan, diketahui rata-rata penerimaan mereka dari usaha perikanan dan non perikanan sebesar Rp. 12.835 .178 pada tahun 2012. Sedangkan rata-rata pengeluaran rumah tangga nelayan terdiri dari biaya biaya kebutuhan rumah tangga, biaya pendidikan, biaya listrik, biaya transportasi, dan biaya lain-lain sebesar Rp. 15.316 .800 pada tahun 2012, dengan rata-rata pengeluaran keluarga nelayan perbulan sebesar Rp. 1.276.400. Dari hasil perhitungan pemasukan dan pengeluaran keluarga nelayan tersebut dapat diketahui Nilai Tukar Nelayan (NTN) di Desa Sungai Kakap Tahun 20012. NTN diperoleh dari perbandingan antara penerimaan rumah tangga nelayan dengan pengeluaran rumah tangga nelayan dalam 1 tahun. NTN dapat bernilai lebih rendah, sama, atau lebih tinggi dari satu. NTN lebih rendah dari satu artinya keluarga nelayan mempunyai daya beli yang rendah dalam memenuhi kebutuhan hidupnya dan berpotensi mengalami defisit anggaran rumah tangga. NTN yang berada di sekitar angka satu artinya keluarga nelayan hanya dapat memenuhi kebutuhan subsistennya saja. Jika NTN lebih tinggi dari satu artinya keluarga nelayan selain dapat memenuhi kebutuhan subsistennya juga dapat memenuhi kebutuhan sekunder atau tersiernya, atau menabung dalam bentuk investasi barang. Perhitungan Nilai Tukar Nelayan di Desa Sungai Kakap adalah sebagai berikut. 


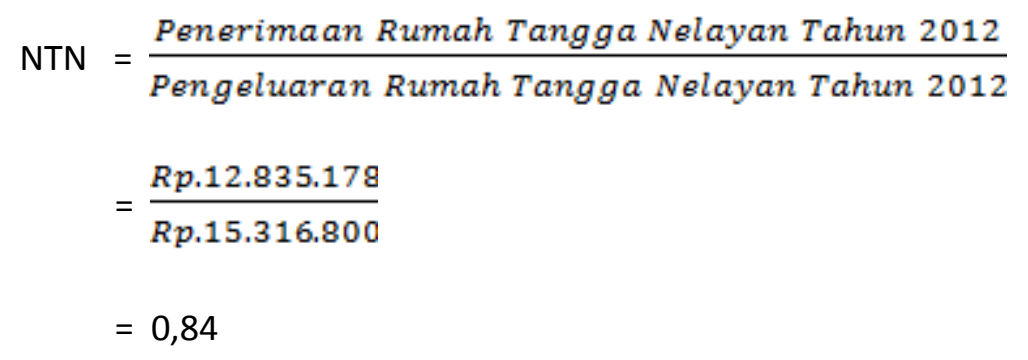

Nilai Tukar Nelayan (NTN) di Desa Sungai Kakap Tahun 2012 sebesar 0,84. Nilai ini mengindikasikan bahwa keluarga nelayan di Desa Sungai Kakap mempunyai daya beli yang rendah dalam memenuhi kebutuhan keluarganya dan mengalami defisit anggaran rumah tangga. Faktor-faktor sebagai penentu besaran pendapatan nelayan di Desa Sungai Kakap antara lain:

1) Perubahan iklim menjadi faktor penting penentu besaran pendapatan nelayan di Sungai Kakap dan juga mempengaruhi tingkat kesejahteraan nelayan, karena sumber pendapatan nelayan di Desa Sungai Kakap semata-mata berasal dari sektor perikanan. Dari hasil analisis mengenai dampak perubahan iklim terhadap hasil tangkapan nelayan di Sungai Kakap diketahui bahwa perubahan iklim yang ditandai dengan curah hujan ekstrim memberi dampak kepada nelayan Sungai Kakap yaitu berkurangnya hasil tangkapan dalam kurun waktu 2009-2012, dan juga secara tidak langsung memberi dampak kepada pendapatan nelayan dan tingkat kesejahteraan nelayan, yang diindikasikan dengan Nilai Tukar Nelayan yang berada dibawah 1.

2) Teknologi, yaitu terkait dengan peralatan yang digunakan oleh nelayan dalam proses penangkapan ikan, seperti perahu, alat pancing, dan jaring. Nelayan yang menjadi responden pada penelitian ini merupakan penduduk asli Desa Sungai Kakap. Nelayan-nelayan tersebut merupakan nelayan tradisional yang menggunakan perahu tanpa mesin sebagai sarana melaut. Alat tangkap yang digunakan juga merupakan alat tangkap tradisional, yaitu dengan menggunakan jaring.

3) Pendidikan dan pengalaman seorang nelayan menentukan keterampilan nelayan dalam melaut, semakin terampil seorang nelayan maka hasil tangkapan cenderung semakin baik. Para nelayan di Desa Sungai Kakap yang menjadi responden pada umumnya merupakan nelayan yang telah melaut selama lebih dari 15 tahun yaitu sebanyak $64 \%$ dari total responden, sebanyak $27 \%$ nelayan telah melaut selama 10-15 tahun, dan sebanyak $9 \%$ nelayan yang telah melaut selama 5-10 tahun, namun juga memiliki tingkat pendidikan yang rendah yaitu rata-rata Tamat SD dengan persentase sebesar $50 \%$. Sisanya adalah nelayan dengan tingkat pendidikan Tamat SMP sebanyak 30\%, Tamap SMA sebanyak 10\% dan Tidak Tamat SD sebanyak 10\%

\section{Strategi Adaptasi Nelayan di Desa Sungai Kakap}

Nelayan di Desa Sungai Kakap memiliki strategi adaptasi terhadap perubahan iklim, walaupun tidak jarang juga ditemui nelayan yang tidak melakukan kegiatan apa-apa ketika hasil tangkapan menurun, ataupun ketika tidak dapat melaut. Strategi adaptasi yang dilakukan oleh keluarga nelayan ialah menjalani pekerjaan sampingan (penerapan pola nafkah ganda), umumnya dilakukan oleh para istri. Penerapan pola nafkah ganda tersebut menjadi strategi untuk menunjang kehidupan perekonomian keluarga nelayan yang tidak lagi dapt bergantung sepenuhnya pada kegiatan melaut. Menurut Satria (2002) pengembangan strategi nafkah ganda ini bertujuan agar nelayan tidak bergantung pada hasil penangkapan saja. Hal ini perlu dilakukan terutama pada nelayan lapisan bawah dimana keterbatasan sarana yang dimiliki menyebabkan nelayan tidak selalu dapat melaut sepanjang tahun.Pola nafkah ganda yang dilakukan adalah dengan menjadi buruh dalam proses pembuatan kerupuk ikan yang memang proses produksinya dilakukan di Desa Sungai Kakap. Namun hal ini tidak berlaku untuk semua keluarga nelayan yang menjadi responden penelitian, hanya sebagian kecil keluarga nelayan yang menjadi responden yang memiliki pekerjaan sampingan, sisanya hanya bergantung dari hasil tangkapan dalam melaut. 
Berikut ini beberapa rekomendasi kebijakan dibeberapa bidang sebagai alternatif strategi adaptasi yang dapat dilakukan oleh nelayan di Desa Sungai Kakap.

1) Bidang kemanusiaan

Nelayan di Desa Sungai Kakap harus memiliki alternatif mata pencaharian selain menangkap ikan. Hal tersebut dilakukan agar nelayan dapat tetap memiliki penghasilan ketika volume produksi nelayan menurun. Cara yang dapat dilakukan adalah dengan membudidayakan ikan laut maupun air tawar dan mengolah ikan hasil tangkapan sehingga nilai ekonomi nya menjadi lebih tinggi. Selain itu, nelayan juga sebaiknya diberikan pelatihan agar mereka memiliki keahlian lain selain melakukan penangkapan, sehingga apabila produksi tangkapan menurun, para nelayan dapat melakukan kegiatan lain dapat mendatangkan pemasukan tambahan bagii keluarganya.

2) Bidang ekosistem

Indonesia merupakan salah satu negara yang dapat mengurangi dampak perubahan iklim. Hutan yang kita miliki berperan besar dalam penyerapan dan penyimpanan karbon. Namun saat ini hutan di Indonesia mengalami ancaman deforestasi. Defoorestasi adalah perubahan kondisi penutupan lahan dari hutan menjadi bukan hutan. Adanya penebangan hutan secara ilegal dan pembakaran hutan dapat membuat Indonesia secara perlahan kehilangan hutan yang dimilikinya sehingga area hutan yang dapat menyerap gas karbon pun semakin berkurang. Hal tersebut harus dicegah agar hutan Indonesia tetap lestari. Partisipasi dari berbagai pihak, seperti pemerintah dan masyarakat yang tinggal di sekitar hutan sangat dibutuhkan agar hutan tetap terjaga. Selain itu, diperlukan adanya integrasi kebijakan pengelolaan ekosistem antara daratan dan lautan.

3) Bidang pemerintahan

Pemerintah dan stakeholder lainnya diharapkan dapat membantu kesulitan nelayan dengan memberikan bantuan berupa peningkatan kapal dan alat tangkap. Hal ini dilakukan agar tercipta diversifikasi alat tangkap dan armada sehingga cakupan areal tangkapan nelayan semakin luas dan diharapkan volume tangkapan nelayan ikut meningkat.

\section{Kesimpulan}

Berdasarkan hasil penelitian mengenai analisis dampak perubahan iklim terhadap tingkat kesejahteraan nelayan di Desa Sungai Kakap, dapat disimpulkan beberapa hal sebagai berikut:

1. Perubahan iklim yang saat ini telah terjadi berdampak secara tidak langsung terhadap aktivitas nelayan di Desa Sungai Kakap. Dari ketiga aspek yang ditinjau (curah hujan, arah dan kecepatan angin, serta tinggi gelombang), faktor yang memiliki dampak paling besar terhadap turunnya hasil tangkapan nelayan adalah curah hujan, karena lingkup penelitian ini dibatasi pada daerah pesisir sehingga arah dan kecepatan angin serta tinggi gelombang tidak memberi dampak terhadap nelayan dalam melaut. Curah hujan yang tinggi memberi dampak terhadap salinitas air laut sehingga menyebabkan turunnya volume produksi tangkapan nelayan meski tidak semua nelayan di Desa Sungai Kakap menyadari hubungan perubahan iklim dan hasil tangkapan tersebut. Curah hujan rata-rata dalam kurun waktu 2008-2012 di Sungai Kakap adalah 2.662,4 $\mathrm{mm}$ dengan penurunan hasil tangkapan dari tahun 2009-2012 sebesar 3.316,7 ton.

2. Nilai Tukar Nelayan (NTN) di Desa Sungai Kakap tahun 2012 adalah 0,84 sehingga mengindikasikan bahwa keluarga nelayan di Desa Sungai Kakap mempunyai daya beli yang rendah dalam memenuhi kebutuhan keluarganya dan mengalami defisit anggaran rumah tangga.

3. Strategi adaptasi yang dilakukan keluarga nelayan merupakan strategi internal yaitu yang berasal dari keluarga nelayan itu sendiri, yaitu dengan menerapkan pola pendapatan ganda meski tidak semua keluarga nelayan memiliki strategi adaptasi untuk menyikapi turunnya produksi tangkapan nelayan. 


\section{Ucapan Terima Kasih}

Penulis mengucapkan terima kasih yang sebesar-besarnya kepada Tuhan Yesus Kristus atas rahmat dan karunia yang telah diberikan selama ini. Ibu saya Asmini Parura,SH,MKn yang tiada hentinya memberikan doa, dan semangat dalam menjalankan skripsi ini. Tidak lupa juga penulis ucapkan kepada Ibu Ir. Hj. Kartini, MT dan Ibu Erni Yuniarti, ST, M.Si sebagai pembimbing serta Bapak Ir. Syahrudin, MT dan Ibu Yulisa Fitrianingsih, ST, MT sebagai penguji. Serta teman-teman dan semua pihak yang tidak dapat saya sebutkan satu per satu yang telah banyak membantu baik dalam bentuk doa, tenaga, maupun motivasi.

\section{Referensi}

Harto, Sri. 2000. Hidrologi: Teori, Masalah, Pemyelesaian. Yogyakarta: Nafiri

Hayes, LM. Dan Laevastu. 1982. Fisheries Oceanography and Ecology. England: Fishing New Books Ltd.

Satria, Arif. 2002. Pengantar Sosiologi Masyarakat Pesisir. Jakarta: Cidesindo 2009. Pesisir dan Laut Untuk Rakyat. Bogor: IPB Press

Ustriyana, I N. G. 2005. Model dan Pengukuran Nilai Tukar Nelayan (Kasus Kabupaten Karangasem). http://ejournal.unud.ac.id/abstrak/\%288\%29\%20soca-ustriyananilai\%20tukar\%20nelayan\%281\%29.pdf 